\title{
No Evidence for Serological Autoimmunity to Islet Cell Heat Shock Proteins in Insulin Dependent Diabetes
}

\author{
Mark A. Atkinson, * Lynn A. Holmes," David W. Scharp, ${ }^{*}$ Paul E. Lacy, ${ }^{\ddagger}$ and Noel K. Maclaren* \\ Department of Pathology and Laboratory Medicine, ${ }^{*}$ College of Medicine, University of Florida, Gainesville, Florida 32610; \\ and Departments of Surgery \& Pathology, ${ }^{\ddagger}$ Washington University School of Medicine, St. Louis, Missouri 63110
}

\begin{abstract}
Recent studies in nonobese diabetic mice have implicated the autoimmune destruction of pancreatic islet cells with immunity to a $\beta$ cell protein cross-reactive to Mycobacterium tuberculosis heat shock protein 65 (hsp 65). Therefore, our studies examined serological immunity to islet cell hsp in humans with insulin-dependent diabetes (IDD). Heat shock of human islet cells in vitro markedly increased the synthesis of proteins of 72,000 , 75,000 , and $90,000 M_{r}$. No autoantibodies reactive to these hsp, nor to the constituently expressed islet cell hsp 65 protein (identified as $60,000 M_{\mathrm{r}}$ ) were observed in IDD patients. The islet cell $64,000-M_{\mathrm{r}}$ autoantigen and hsp 65 proteins were physiologically and immunocompetitivly distinct. These experiments do not support the hypothesis that IDD in humans is associated with autoimmunity to islet cell heat shock proteins. (J. Clin. Invest. 1991. 87:721-724.) Key words; autoantibodies $\bullet$ autoantigens
\end{abstract}

\section{Introduction}

The clinical onset of insulin-dependent diabetes (IDD) ${ }^{1}$ is characterized by inflammation within the islets (insulitis) and specific loss of the majority of the insulin-producing $\beta$ cells (1). In IDD patients, serological autoimmunity is represented by autoantibodies to islet cell cytoplasmic, surface, and insulin autoantigens (2). In man $(3,4)$, the Biobreeding rat $(5)$, and the nonobese diabetic (NOD) mouse (6), IDD has also been characterized by autoantibodies directed against an islet $\beta$ cell protein of $64,000 M_{\mathrm{r}}$. However, the role of these autoantibodies in the immunological destruction of $\beta$ cells remains unclear.

Recent evidence has suggested that a $\beta$ cell target antigen in NOD mice is a molecule cross-reactive with the $65-\mathrm{kD}$ heat shock protein (hsp 65) of Mycobacterium tuberculosis (7). In that study, IDD was associated with anti-hsp 65 antibodies,

Address correspondence and reprint requests to Dr. Noel K. Maclaren, Chairman and Professor, Department of Pathology, Box J-275, JHMHC, Gainesville, FL 32610.

Received for publication 7 September 1990 and in revised form 18 Ocrober 1990.

1. Abbreviations used in this paper: hsp, heat shock protein; IDD, insulin-dependent diabetes; NOD, nonobese diabetic.

J. Clin. Invest.

(c) The American Society for Clinical Investigation, Inc.

$0021-9738 / 91 / 02 / 0721 / 04 \$ 2.00$

Volume 87, February 1991, 721-724 and $T$ cell clones reactive to mycobacterial hsp 65 were able to induce insulitis and hyperglycemia in young NOD mice. Also, the $64,000-M_{\mathrm{r}}$ protein was recently proposed by one group to be glutamic acid decarboxylase (8), while a second group reported the protein to be hsp 65 (9). Therefore, the goal of our studies was to test human IDD patients for evidence of anti-islet cell hsp autoantibodies including that to the islet cell protein analogous to hsp 65 . We also tested for potential antigenic cross-reactivity between the islet cell hsp 65 antigen and the $64,000-M_{\mathrm{r}}$ islet cell autoantigen.

\section{Methods}

Patient sera and monoclonal antibodies. Sera from two groups of individuals were selected from a previous study (4) for the analyses presented here. There were seven new onset IDD patients (four males/ three females, age $13 \pm 11.4 \mathrm{yr}$ ) of whom five were autoantibody positive to the $64,000-M_{\mathrm{r}}$ autoantigen. Six nondiabetic controls (three males/three females, age $15 \pm 7.3 \mathrm{yr}$ ) without any known family history of autoimmune disease were also analyzed. Mouse IgG, MAb IT-13 (suppliers designation WTB 78-A 1) (10) reactive to the hsp 65 of mycobacterium tuberculosis was obtained from the World Health Organization (Immunology of Tuberculosis [IMMTUB] monoclonal antibody bank at the Center for Disease Control, Atlanta, GA).

Human islet cells. Human pancreatic islets were isolated from cadaveric pancreases (11) and maintained in vitro as previously described (4). The islet cells were metabolically labeled with $\left[{ }^{35}\right.$ S $]$ methionine (Amersham Corp., Arlington Heights, IL) in vitro $\left(95 \%\right.$ air $\left./ 5 \% \mathrm{CO}_{2}\right)$. Cells were labeled for $4 \mathrm{~h}$ at $37^{\circ} \mathrm{C}(4)$, or labeled for $2 \mathrm{~h}$ at $37^{\circ} \mathrm{C}$ followed by incubation at $41^{\circ} \mathrm{C}$ for an additional $2 \mathrm{~h}$ (12).

Islet cell extractions and immunoprecipitations. Islet cells were extracted as previously described (4) with the following modification. No phase separation was performed after detergent extraction $\left(2 \mathrm{~h}, 4^{\circ} \mathrm{C}\right)$ and ultracentrifugation $\left(100,000 \mathrm{~g}, 45 \mathrm{~min}, 4^{\circ} \mathrm{C}\right)$. Supernatants containing islet cell protein extracts were collected for total protein analyses or immunoprecipitation. For total protein analysis, equivalent aliquots of the islet cell extract were separated by SDS-PAGE according to Laemmli (13), and subjected to fluororadiography. For immunoprecipitation studies (performed on two occasions), the cell islet lysates were precleared by incubation $\left(2 \mathrm{~h}, 4^{\circ} \mathrm{C}\right)$ with either control or IDD serum (100 $\mu \mathrm{l})$, or IT-13 MAb ( $1 \mu \mathrm{l}$ in $99 \mu \mathrm{l}$ of Tris buffer [4]) for every 1,000 islets. Immune complexes were then adsorbed with an excess of protein A Sepharose CL-4B (Pharmacia Fine Chemicals, Piscataway $\mathrm{NJ})$. Aliquot volumes representing 1,000 islet cells containing unbound (precleared) lysate were then incubated $\left(18 \mathrm{~h}, 4^{\circ} \mathrm{C}\right)$ with either coded samples of IDD or control sera $(25 \mu \mathrm{l})$, or IT-13 MAb $(1 \mu \mathrm{l}$ in 25 $\mu \mathrm{l}$ Tris buffer). After another incubation with protein A Sepharose CL4B $\left(1 \mathrm{~h}, 4^{\circ} \mathrm{C}\right)$, the complexes were then washed five times with $50 \mathrm{mM}$ Tris-HCL (pH 7.4) with $0.1 \%$ SDS, $1.0 \%$ Triton X-114, and $2 \mathrm{mM}$ EDTA, and then washed again one time in double distilled water (4). The protein A sepharose CL-4B was then boiled in Laemmli sample buffer (13), and samples subjected to SDS-PAGE and fluororadiog- 
raphy. All fluororadiographs were analyzed independently by two observers without knowledge of test sample identity. Recombinant human hsp 65, termed P1 protein (14), was obtained for confirmation of the identification of islet cell hsp 65. Statistical analysis was performed using the Fisher's exact test.

\section{Results}

Our initial studies determined alterations in protein synthesis in islet cells subjected to heat shock treatment in vitro. Equivalent numbers of intact human islet cells $\left(1.0 \times 10^{4}\right)$ were metabolically labeled at $37^{\circ} \mathrm{C}$ or under heat shock conditions, followed by a total cell detergent extract. The total incorporated counts per minute of solubilized islet cell protein extract labeled at $41{ }^{\circ} \mathrm{C}$ was reduced $50.7 \%$ to that of islets labeled at $37^{\circ} \mathrm{C}\left(1.10 \times 10^{8}\right.$ vs. $\left.2.23 \times 10^{8} \mathrm{cpm}\right)$. Aliquots representing equivalent volumes of these extracts were then analyzed by one-dimensional SDS-PAGE and fluororadiography. Fig. 1 displays total protein extracts from islet cells labeled at $37^{\circ} \mathrm{C}$ (lane $A$ ) or heat shocked (lane $B$ ). Heat shock markedly increased the synthesis of proteins of 72,000,75,000, and 90,000 $M_{\mathrm{r}}$. This observation was consistent with other studies of heat shock of mammalian cells (15), and potential classification of these islet cell hsp may be inferred by their relative molecular mass. In our studies, the $72,000-M_{\mathrm{r}}$ protein was not readily visible in cells cultured at $37^{\circ} \mathrm{C}$ (Fig. 1 lane $A$ ), but its production increased under heat shock conditions (Fig. 1 lane $B$ ). The hsp 70 family contains a $72-\mathrm{kD}$ hsp that is not obvious in cells grown at $37^{\circ} \mathrm{C}$, and its induction due to heat shock represents the major translational activity of the stressed cell (13). The $75,000-M_{\mathrm{r}}$ islet cell protein (Fig. 1 lane $B$ ) may represent the recently identified mitochondrial stress protein grp 75 (16).

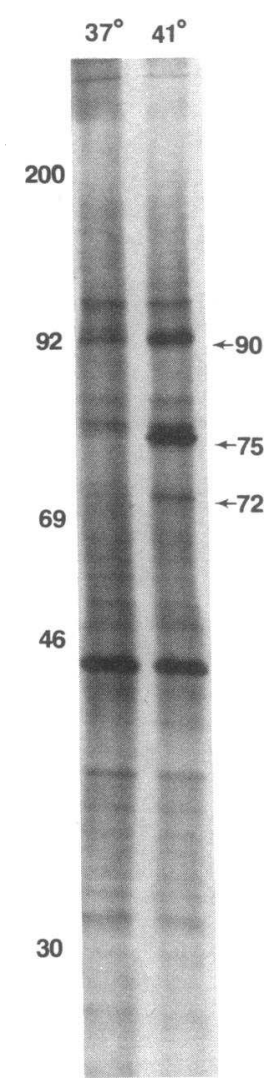

Figure 1. Fluororadiograph of SDS-PAGE separated proteins extracted from islet cells metabolically labeled in vitro at $37^{\circ} \mathrm{C}$ (lane $A$ ) or heat shock conditions (lane $B$ ). Estimated molecular masses (in $\mathrm{kD}$ ) are indicated at the left margin, and identification of proteins sensitive to heat induction are indicated on the right margin.
The synthesis of grp 75 was reported to increase 2-5-fold depending on the stress conditions (16), being most sensitive to glucose deprivation. However, in our studies islet cells were not labeled under conditions of glucose deprivation. Therefore, the identity of the islet cell $75,000-M_{\mathrm{r}}$ protein will require further examination. The hsp 90 family contains a $90-\mathrm{kD}$ hsp that is abundant in cells at $37^{\circ} \mathrm{C}$, however its synthesis has been reported to increase $\sim 3-5$-fold after induction of stress (15). The equivalent level of increase in synthesis was readily apparent in the $90,000-M_{\mathrm{r}}$ protein after the heat shock treatment (Fig. 1). As our extraction methods did not attempt localization, the origin of the 72,000-, 75,000-, and $90,000-M_{\mathrm{r}}$ islet cell hsp was not determined.

Sera from seven new onset IDD patients and six healthy control persons, as well as MAb IT-13, were used for immunoprecipitation of islets metabolically labeled at $37^{\circ} \mathrm{C}$, or under heat shock conditions. In experiments where the preclearing sera was that from normal control origin, the five $64,000-M_{\mathrm{r}}$ autoantibody containing IDD sera immunoprecipitated the $64,000-M_{\mathrm{r}}$ islet cell autoantigen from islets labeled at $37^{\circ} \mathrm{C}$. None of the six control sera $(P<0.01$ vs. IDD), the two $64,000-M_{\mathrm{r}}$ autoantibody negative IDD sera, nor MAb IT-13 immunoprecipitated the $64,000-M_{\mathrm{r}}$ protein from this islet cell preparation. However, as shown in the representative gels (Fig. 2), the MAb IT-13 most strongly immunoprecipitated a band of $60,000 M_{\mathrm{r}}$ (Fig. $2 A$, lane $C$ ), thereby identifying this molecule as the islet cell equivalent of hsp 65. The IT-13 MAb also reacted to a lesser extent with bands of 52,000 and 48,000 $M_{\mathrm{r}}$. The reason for the latter multiple reactivities is unknown, but has been reported in a previous study using IT-13 MAb to Mycobacteria hsp $65(10,12)$. A distinct difference in migration in SDS-PAGE of the $64,000-M_{\mathrm{r}}$ autoantigen obtained by immunoprecipitation using 64,000- $M_{\mathrm{r}}$ autoantibody containing sera from a patient with IDD (Fig. 2 lane $A$ ), and the islet cell hsp $65\left(60,000 M_{\mathrm{r}}\right)$ obtained with the IT-13 MAb (Fig. $2 A$, lane $C$ ) was observed.

In parallel experiments, extracts from heat shocked islet cells were precleared with identical control sera. Under these conditions, the same five IDD sera immunoprecipitated the $64,000-M_{\mathrm{r}}$ islet cell autoantigen, however the amount of protein present was noticeably reduced from that obtained by labeling islets at $37^{\circ} \mathrm{C}$. None of the six control sera, the two $64,000-M_{\mathrm{r}}$ autoantibody negative IDD sera, nor IT-13 MAb immunoprecipitated the $64,000-M_{\mathrm{r}}$ protein from this preparation. The IT-13 MAb again immunoprecipitated the band of $60,000 M_{\mathrm{r}}$ (Fig. $2 B$, lane $C$ ), and the amount of protein present was not reduced by the heat shock treatment. In contrast, the amount of $64,000-M_{\mathrm{r}}$ protein obtained with IDD sera (Fig. $2 B$, lane $A$ ) was significantly reduced from that obtained using the same serum sample as used in Fig. $2 A$ (lane $A$ ). Most interesting, none of the seven IDD or six control sera tested specifically immunoprecipitated any of the islet cell heat shock proteins, including the hsp 65 , or the 72,000-, 75,000-, and 90,000- $M_{\mathrm{r}}$ proteins identified in Fig. 1.

To test for antigenic/epitope cross-reactivity between the $64,000-M_{\mathrm{r}}$ autoantigen and the hsp 65 , a series of competition studies were undertaken. For these studies, a pool of three IDD sera known to contain $64,000-M_{\mathrm{r}}$ autoantibodies were used as a positive standard reagent. As shown in Fig. 3, immunoprecipitation with the positive (lane $A$ ) or control (lane $B$ ) sera of islet cell extracts, which had been precleared with control sera, resulted in the immunoprecipitation of the $64,000-M_{\mathrm{r}}$ autoanti- 

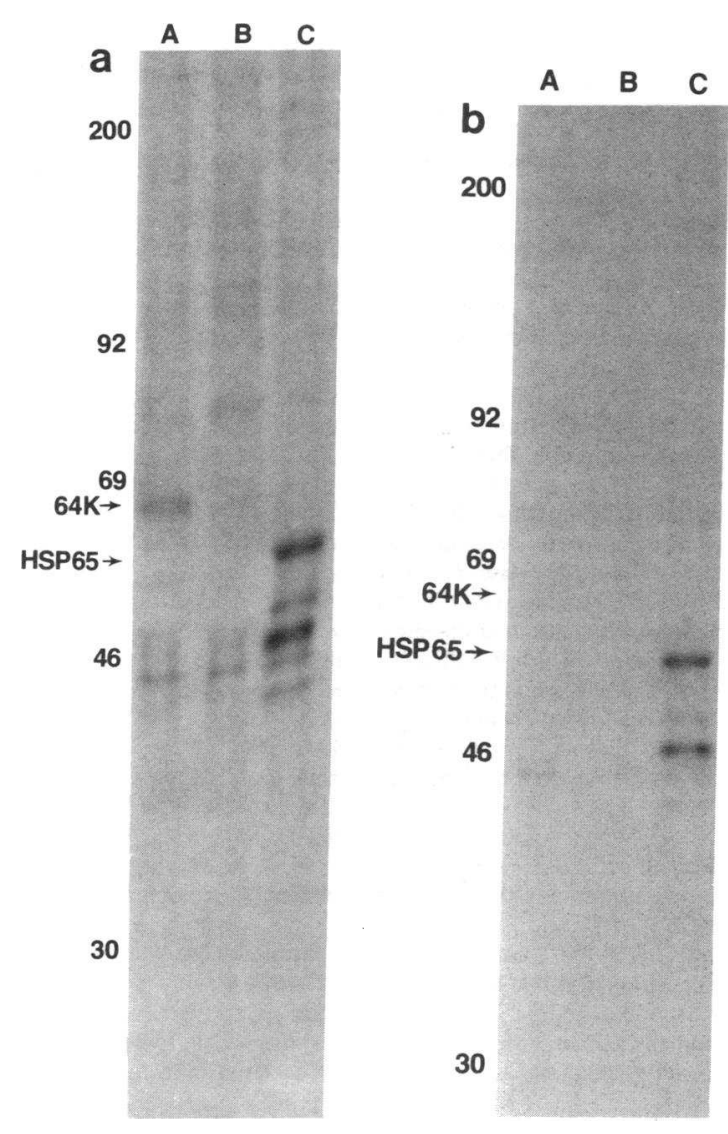

Figure 2. Fluororadiograph of SDS-PAGE separated immunoprecipitates of extracts from islet cells metabolically labeled at $37^{\circ} \mathrm{C}$ (a) or $41^{\circ} \mathrm{C}$ (b), using a newly diagnosed IDD sera (lane $A$ ), control sera (lane $B$ ), or the IT-13 MAb (lane $C$ ). The $64,000-M_{\mathrm{r}}$ and hsp 65 proteins are indicated by arrows.

gen only with IDD sera. As expected, when IT-13 MAb was used as a preclearing reagent of islet cell extracts, immunoprecipitation of hsp 65 using IT-13 MAb was markedly reduced (Fig. 3, lane $C$ ). However, the use of IT-13 MAb as a preclearing reagent had no effect on the quantity of $64,000-M_{\mathrm{r}}$ autoantigen immunoprecipitated by IDD sera (Fig. 3, lane $D$ ). Whereas this anti-64,000- $M_{\mathrm{r}}$ reactivity could be removed when IDD sera was used as a preclearing reagent (Fig. 3, lane $E$ ), preclearance with IDD sera did not effect the ability of MAb IT-13 to immunoprecipitate hsp 65 (Fig. 3, lane $F$ ).

To confirm the human hsp 65 cross-reactivity with the IT$13 \mathrm{MAb}$, the antibody was first incubated in the presence of recombinant $\mathrm{P} 1$ protein $\left(1 \mu \mathrm{g} / \mathrm{ml}, 3 \mathrm{~h}, 4^{\circ} \mathrm{C}\right)$, the human hsp 65 homologue (14). After this preadsorption, the IT-13 MAb markedly decreased in its ability to immunoprecipitate islet cell hsp 65, however preincubation of IDD sera with recombinant $\mathrm{Pl}$ under the same conditions did not effect the ability of the sera to immunoprecipitate $64,000-M_{\mathrm{r}}$ islet cell autoantigen (data not shown).

\section{Discussion}

Exposure of cells and organisms to heat shock induces a physiological response termed the heat shock response, which is associated with the synthesis of specific hsp (17). The heat shock response represents an immediate, complex, and transient re-

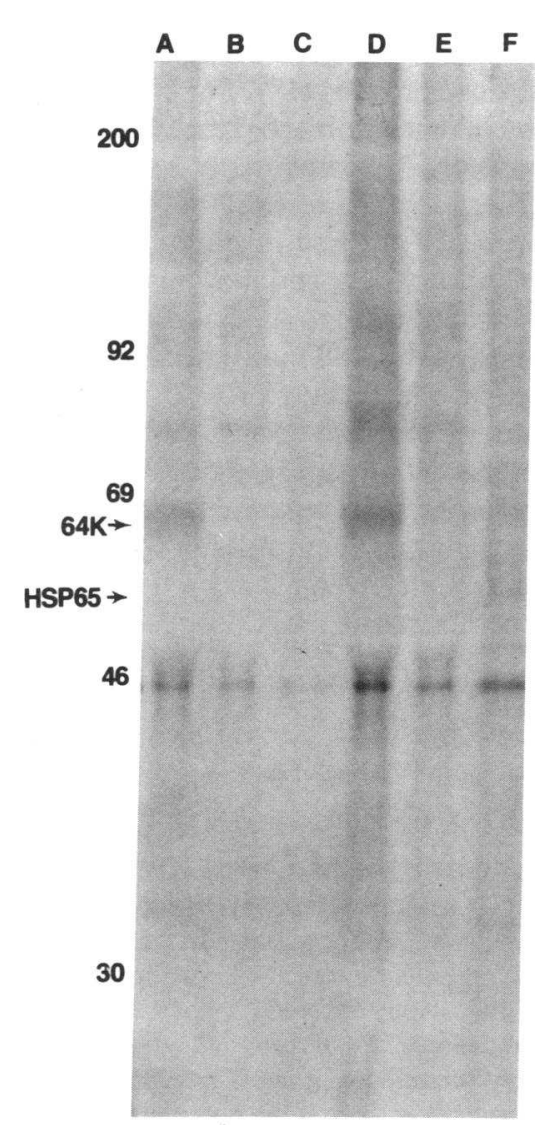

Figure 3.

Fluororadiograph of SDS-PAGE separated immunoprecipitates of extracts from islet cells metabolically labeled at $37^{\circ} \mathrm{C}$, using a newly diagnosed IDD (lane $A$, $D$, and $E$ ) or control (lane $B$ ) sera, or the IT13 (lane $C$ and $F$ ) MAb. The 64,000- $M_{\mathrm{r}}$ and hsp 65 proteins are designated with arrows.

programming of cellular activities, consisting of induction of transcription and synthesis of hsp, and posttranscriptional inhibition of normal protein synthesis. The heat shock response is not only induced by exposure to elevated temperatures, but also by cellular injury, oxidative injury, viral infections, heavy metals, ethanol, amino acid analogues, and inhibitors of energy metabolism. Several groups have suggested a link between the mediators of fever (interleukin 1, interleukin 2, tumor necrosis factor, and interferons) and the heat shock response (16). Cells deprived of glucose also express a unique family of stress induced proteins (15).

In these studies, analysis of protein extracts obtained from islet cells subjected to heat shock revealed the expected observation of a decrease in total protein synthesis. However, SDSPAGE revealed a specific increase in the synthesis of proteins of $72,000,75,000$, and $90,000 M_{\mathrm{r}}$ with heat shock treatment in vitro.

It is possible that heat shock or stress could induce the formation of these three proteins in islet cells in vivo, and thus might present themselves as immunological target antigens in persons developing IDD. However, we observed no evidence for autoimmunity to these proteins as assessed by autoantibody reactivity, since sera from seven new onset IDD patients were unable to immunoprecipitate any of these proteins from islet cells heat shocked in vitro.

Our studies do not support the report by Jones et al. (9) that hsp 65 may represent the $64,000-M_{\mathrm{r}}$ autoantigen. Those studies suggested that the $64,000-M_{\mathrm{r}}$ protein was induced by stress, and that immunoprecipitation of hsp 65 using monoclonal antibodies to hsp 65 was inhibited by IDD sera. Unfortunately, neither of these findings was described with experimental de- 
tails nor the control experiments showing competition between the antibodies for these islet cell proteins (18). Our studies, in fact, are in direct opposition in that we observed the $64,000-M_{\mathrm{r}}$ protein synthesis to be markedly decreased under heat shock conditions. We also established that the monoclonal antibody to hsp 65 reacted to a protein of a different migration in SDSPAGE than the $64,000-M_{\mathrm{r}}$ autoantigen, and that no immune competition existed between antibodies to these proteins.

As previously mentioned, Elias and colleagues have recently reported the induction and therapy of IDD in NOD mice by hsp 65 (7). However, we observed no autoantibodies in our patients with IDD that reacted to hsp $65\left(60,000 M_{\mathrm{r}}\right)$. That serological autoimmunity to hsp may underlie the autoimmune pathogenesis of IDD cannot be confirmed nor supported by these studies of humans. Whether a cellular restricted immunity to islet cell hsp exists in humans with IDD is the subject of ongoing investigations.

\section{Acknowledgments}

We thank Dr. Radhey Gupta for the supply of P1 protein, Dr. Thomas Shinnick for the gift of MAb IT-13, and the National Disease Research Interchange for procuring the human pancreas as used in these studies.

This work was supported by grants from the National Institutes of Health (POI DK-39079 [Gainesville] and ROI DK-4046901 [St. Louis]) and the Edison Foundation. Dr. Atkinson is supported by a Juvenile Diabetes Foundation International grant (189137) and is the recipient of a Career Development award from the American Diabetes Association.

\section{References}

1. Atkinson, M. A., and N. K. Maclaren. 1990. What causes diabetes? Sci. Am. 7:62-67.

2. Eisenbarth, G. 1986. Insulin dependent diabetes mellitus: a chronic autoimmune disease. N. Engl. J. Med. 314:1360-1368.
3. Baekkeskov, S., J. H. Nielsen, B. Marner, T. Bilde, J. Ludvigsson, and A. Lernmark. 1982. Autoantibodies in newly diagnosed diabetic children immunoprecipitate human pancreatic islet cell proteins. Nature (Lond.). 298:167-169.

4. Atkinson; M. A., N. K. Maclaren, D. W. Scharp, P. E. Lacy, and W. J. Riley. 1990, 64,000 $M_{\mathrm{r}}$ autoantibodies are predictive of insulin dependent diabetes. Lancet. 335:1357-1360.

5. Baekkeskov, S., T. Dyrberg, and A. Lernmark. 1984. Autoantibodies to the 64 kilodalton islet cell protein precede the onset of spontaneous diabetes in the BB rat. Science (Wash. DC). 224:1348-1350.

6. Atkinson, M. A., and N. K. Maclaren. 1988. Autoantibodies in nonobese diabetic mice immunoprecipitate an $64,000 M_{\mathrm{r}}$ islet cell antigen. Diabetes. 37:1587-1590.

7. Elias, D., D. Markovits, T. Reshef, R. van der Zee, and I. R. Cohen. 1990. Induction and therapy of autoimmune diabetes in the non-obese diabetic mouse by a $65-\mathrm{kDa}$ heat shock protein. Proc. Natl. Acad. Sci. USA. 87:1576-1580.

8. Baekkeskov, S., H. Jan-Aanstoot, S. Christgau, A. Reetz, M. Solimena, M. Cascalho, F. Folli, H. Richter-Olesen, and P. De-Camilli. 1990. Identification of the $64 \mathrm{~K}$ autoantigen in insulin-dependent diabetes as the GABA-synthesizing enzyme glutamic acid decarboxylase. Nature (Lond.). 347:151-156.

9. Jones, D. B., N. R. Hunter, and G. W. Duff. 1990. Heat shock protein 65 as a $\beta$ cell antigen of insulin-dependent diabetes. Lancet. 335:583-585.

10. Letter to the Editor. 1986. Results of a World Health Organization-sponsored workshop to characterize antigens recognized by mycobacterium-specific monoclonal antibodies. Infect. Immun. 51:719-732.

11. Ricordi, C., P. E. Lacy, E. H. Finke, B. J. Olack, and D. W. Scharp. 1988. Automated method for isolation of human pancreatic islets. Diabetes. 37:413420.

12. Shinnick, T., M. H. Vodkin, and J. C. Williams. 1988. The Mycobacterium tuberculosis 65 -kilodalton antigen is a heat shock protein which corresponds to common antigen and to the Escheria coli GroEL protein. Infect. Immun. 56:446-451.

13. Laemmli, U. K. 1970. Cleavage of structural proteins during the assembly of the head of bacteriophage T4. Nature (Lond.). 227:680-685.

14. Jindal, S., A. K. Dudani, B. Singh, C. B. Harley, and R. Gupta. 1989 Primary structure of a human mitochondrial protein homologous to the bacterial and plant chaperonins and to the 65-kilodalton Mycobacterial antigen. Mol. Cell. Biol. 9:2279-2283.

15. Welch, W. J., L. A. Mizzen, and A. P. Arrigio. 1989. Structure and function of mammalian stress proteins. In Stress-induced Proteins. M. L. Pardue, J. R. Feramisco, and S. Lindquist, editors. UCLA Symposia Series. Alan R. Liss Inc., New York. 187-201.

16. Mizzen, L. A., C. Chang, J. I. Garrels, and W. J. Welch. 1989. Identification, characterization, and purification of two mammalian stress proteins present in mitochordria, grp 75, a member of the hsp 70 family, and hsp 58, a homolog of the bacterial groEL protein. J. Biol. Chem. 264:20664-20675.

17. Kaufmann, S. H. E. 1990. Heat shock proteins and the immune response. Immunol. Today. 4:129-131.

18. Editorial. 1990. The $64 \mathrm{~K}$ question in diabetes. Lancet. 336:597-598. 